\title{
Bricolage and Social Entrepreneurship to Address Emergent Social Needs: A "Deconstructionist" Perspective
}

\section{Lamberto Zollo', Riccardo Rialti², Cristiano Ciappei ${ }^{3}$, Andrea Boccardi4}

\begin{abstract}
Social entrepreneurship is one of the most discussed issues in recent management literature. In particular, social entrepreneurship has recently gained the attention of management scholars interested in understanding its sociological and anthropological aspects. This paper focuses on Claude Lévi-Strauss's notion of "bricolage" and the way it can represent a significant opportunity to address emergent social needs. Building on a postmodernist philosophical perspective, namely Jacques Derrida's "deconstructionism," we attempt to unpack the bricolage phenomenon within the social entrepreneurship field. Following the findings of an in-depth longitudinal case study, we provide a theoretical conceptualization of possible entrepreneurial solutions to social needs, exploring the significant role of bricolage that is consequently interpreted as a suitable entrepreneurial opportunity to address particular types of social needs that we shall define, in a way, as emergent.
\end{abstract}

Keywords: social entrepreneurship, bricolage, non-profit organizations, deconstructionism, complexity, emergencies management.

\section{INTRODUCTION}

Entrepreneurship has traditionally represented one of the most explored fields in the managerial literature (Shane \& Venkataraman, 2000; Anderson \& Starnawska, 2008; Garba, Djafar \& Mansor, 2013). Even though a univocally

1 Lamberto Zollo, University of Florence (DISEI - Department of Economics and Management), Via delle Pandette 32, 50127, Florence (Italy); e-mail: lamberto.zollo@unifi.it.

2 Riccardo Rialti, Zollo, University of Florence (DISEI - Department of Economics and Management), Via delle Pandette 32, 50127, Florence (Italy); e-mail: riccardo.rialti@unifi.it.

3 Cristiano Ciappei, University of Florence, University of Florence (DISEI - Department of Economics and Management), Via delle Pandette 32, 50127, Florence (Italy); e-mail: cristiano.ciappei@unifi.it.

4 Andrea Boccardi, University of Florence, , University of Florence (DISEI - Department of Economics and Management), Via delle Pandette 32, 50127, Florence (Italy); e-mail: andrea.boccardi@unifi.it. 
accepted definition of 'entrepreneurship' does not exist yet (Gartner, 1990), entrepreneurial activity has generally been identified as a human activity consisting of "reorganizing the established and crafting the new across a broad range of settings and spaces and for a range of goals such as social change" (Steyaert \& Katz, 2004, p. 182). In this perspective, entrepreneurship literature has focused on the exploration of the role of entrepreneurs in economic growth (Brzozowska, Glinka \& Postula, 2014), on entrepreneurial education (Ciappei, Laudano, Zollo \& Rialti, 2016; Rialti, Pellegrini, Caputo \& Dabic, 2017) and, in addition, on the potential of entrepreneurship in value generation and in the creation of new ventures (Campos, Alvarado Acuña, de la Parra \& Aguilar Valenzuela, 2013; Papzan, Afsharzade \& Moradi, 2013; Zollo, Laudano, Ciappei \& Zampi, 2017a). However, despite the traditional attention of literature on commercial entrepreneurship, as a consequence of the recent attention on sustainable growth and the satisfaction of social needs, such important entrepreneurial topics of research have started to be addressed to social issues and societal challenges too. Hence, social entrepreneurship is emerging as one of the most significant issues within entrepreneurship literature (Mair, Battilana, \& Cardenas, 2012; Zollo, Marzi, Boccardi, \& Surchi, 2015; Zollo, Rialti, Ciappei, \& Pellegrini, 2016b).

Social entrepreneurship has been identified as the form of entrepreneurship characterized not exclusively by the pursuit of economic goals but also by the pursuit of social and environmental objectives (Mair, Battilana \& Cardenas, 2012). Moreover, it has been deemed to be based on collective wisdom and long-term social value creation (Mair \& Marti, 2004; Tan, Williams \& Tan, 2005; Bacq \& Jenssen, 2011). In spite of these significant differences, it is possible to identify a point of contact between traditional or commercial entrepreneurship and social entrepreneurship. In fact, just as commercial entrepreneurs have to arrange a resource-constrained scenario in order to create economic value (Stevenson \& Jarillo, 1990), social entrepreneurs have to gather, rearrange, and reinterpret the available resources for the creation of the social value (Zahra, Gedajlovic, Neubaum \& Shulman, 2009; Di Domenico, Haugh \& Tracey, 2010; Zollo et al., 2016b). In this regard, the typical ability of an entrepreneur to rearrange, reinterpret and exploit the stock of available resources has been assimilated to the anthropological notion of 'bricolage' (Lévi-Strauss, 1966), which represents the main focus of the present research.

Building on these considerations, this paper attempts to explore whether the concept of bricolage may be considered valid in the social entrepreneurship context. Specifically, we will analyze whether bricolage is also a strategy capable of exploiting emerging opportunities to develop solutions to social emergencies. This research, thus, aims at contributing to 
social entrepreneurship literature by exploring the bricolage phenomenon in a contextualized setting, namely social entrepreneurship organizations located in Italy. In this sense, we will study the case of the "Venerabile Arciconfraternita della Misericordia di Firenze" (Confraternity of Mercy of Florence), which is one of the most ancient non-profit organizations in the world and still plays a crucial role in the Italian socio-healthcare scenario (see Zollo, Faldetta, Pellegrini \& Ciappei, 2016a). As a result, a conceptual framework concerning bricolage solutions to address emerging social needs will be theorized.

This paper is structured as follows. Firstly, the theoretical background of bricolage is contextualized within literature on social entrepreneurship. Next, the philosophical perspective of "deconstructionism" is illustrated in order to unpack the bricolage concept in social entrepreneurship. Thirdly, the research setting - the "Venerabile Arciconfraternita della Misericordia di Firenze" - along with the adopted methodology is presented. Then, the empirical findings from the longitudinal case study are discussed along with the exploration of the "social bricolage phenomenon." Finally, implications both at a theoretical and practical level are provided, along with significant avenues for future research.

\section{LITERATURE REVIEW}

\section{Bricolage in social entrepreneurship}

Recently, entrepreneurial bricolage has been considered as one of the leading critical factors for an organization's success and competitiveness, along with the traditional entrepreneurial perspectives of "causation" and "effectuation" (Fisher, 2012; Andries, Debackere \& Looy, 2013; Arend, Sarooghi \& Burkemper, 2015). While causation exists when "an individual entrepreneur decides on a predetermined goal and then selects between means to achieve that goal" (Fisher, 2012, p. 1022), effectuation has been seminally defined by Sarasvathy (2008) as "a logic of entrepreneurial expertise, a dynamic and interactive process of creating new artefacts in the world" (p. 6; see also Sarasvathy, 2001). Building on this, Baker and Nelson (2005) first referred to the notion of entrepreneurial bricolage as "making do by applying combinations of resources at hand to new problems and opportunities" (p. 33), thus stressing its action-oriented and "hands-on" approach (Fisher, 2012, p. 1026; see also George, 2005; Alvarez \& Barney, 2007). Entrepreneurial bricolage is characterized by improvisation and adaptation (Baker, Miner \& Eesley, 2003), resilience, "ritualized ingenuity," experiential memory (Duymedjian \& Rüling, 2010), 
and "refusal to enact" (Di Domenico, Haugh \& Tracey, 2010, p. 685). These features are particularly significant in the dynamic, complex and uncertain entrepreneurship field which is typically and closely connected with social change and societal challenges (Desa, 2012; Pellegrini, Ciappei, Zollo \& Boccardi, 2016). The notion of bricolage was first introduced in Claude Lévi-Strauss's masterpiece, The Savage Mind (1966). This concept has increasingly gained attention in management research (Baker, Miner \& Eesley, 2003; Duymedjian \& Rüling, 2010), and has been increasingly investigated by entrepreneurship scholars (Garud \& Karnøe, 2003; Baker \& Nelson, 2005; Di Domenico et al., 2010; Desa, 2012).

According to Lévi-Strauss's seminal definition (1966, p. 17), bricoleurs overcome environmental constraints due to a scarcity of resources thanks to "making do" of "whatever is at hand," and thanks to the creative recombination of resources for new purposes (Ciborra, 1996; Baker \& Nelson 2005). Specifically, the French anthropologist distinguishes and differentiates bricoleurs from engineers. According to his philosophy, the bricoleur prioritizes opportunities-driven attitudes with resources 'at hand' by creating 'something from nothing' (Lévi-Strauss, 1966) thanks to a reflexive reinterpretation that is derived from their previous experience (Baker et al., 2003; Di Domenico et al., 2010; Zollo, Pellegrini \& Ciappei, 2016c). On the contrary, engineers a priori identify the available resources in order to determine a structure that best fits the contingent environmental events. As a result, it has been assessed that bricoleurs are characterized by the sensemaking ability to implement practical knowledge in a penurious environment (Baker \& Nelson, 2005; Duymedjian \& Rüling, 2010). Thus, they are capable of adapting the "heterogeneous repertoire" (Lévi-Strauss, 1966, p. 17) of already existing resources and reassembling them for new instrumental uses. In other words, bricoleurs "turn back to an already existent set made up of tools and materials, to consider and reconsider what it contains" (LéviStrauss, 1966, p. 18), and they creatively arrange new repertoires that will be instrumentally readapted for new challenges (Duymedjian \& Rüling, 2010).

Because one of the most essential elements of entrepreneurial bricolage is connected to resources, we have deemed it necessary to illustrate the main facets of such a concept. By resources 'at hand' literature we refer to existing organizational mechanisms (Ciborra, 1996) and social network relations (Baker et al., 2003), along with previously learned skills and mechanisms (Hatton, 1989) which constitute the available inventory of the entrepreneur's repertoire (see Moorman \& Miner, 1998; Katila \& Shane, 2005; Duymedjian \& Rüling, 2010). By 'recombination' of resources literature we refer to the original reconciliation of existing organizational mechanisms and to the adjustment, alteration, and arrangement of 
a different combination of resources (Jacob, 1977; Baker \& Nelson, 2005; Garud \& Giuliani, 2013) which aim at recreating the internal disposition of the repertoire's internal parts with a view to a functionally performing repertoire. Such an ingenious recombination enables bricoleurs to exploit the resources latent functions and capacities, thus creating ephemeral rearrangements from the available repertoire and allowing temporary solutions to unexpected contingent emergencies (Lanzara, 1983; Johannisson \& Olaison, 2007). Building on recent literature (Di Domenico et al., 2010), we argue that entrepreneurial bricolage may play a remarkable role in the domain of social entrepreneurship. In fact, entrepreneurs act as social bricoleurs by improvising innovative solutions to immediate complex social problems, thus becoming the agents of change by applying seemingly unfitted resources "at hand" to unexpected social problems (Bacq \& Janssen, 2011). Such an existing gap between available resources and social aim is filled thanks to bricoleurs' ingenious reinterpretation of the vacant function of resources that allows the "creation of something from nothing" (Baker \& Nelson, 2005, p. 336). This interpretative ability enables them to seize multiple 'making do' opportunities in one single resource that they creatively project in an unusual and imaginative combination with other resources, thus creating latent synergic value (Lévi-Strauss, 1966). In this way, the typical use of a resource is disarranged in order to adapt its capacity to seemingly unfitting objectives. As a consequence, it is clear that social bricoleurs share the common features of social entrepreneurs, namely skilful management of unexpected opportunities, spontaneous innovation, improvised risk, resources differently rearranged to social value creation (Peredo \& McLean, 2006; Bacq \& Janssen, 2011). Actually, the "social dimension" of bricolage (Johannisson \& Olaison, 2007, p. 55) becomes extremely important when unpredicted and emergent situations arise and entrepreneurial bricoleurs have to spontaneously improvise an innovative and rapid solution making use of the available repertoire of resources (Di Domenico et al., 2010). Hence, we stress the importance of the social aspects of bricolage such as relational capacity, network implementation, spontaneous cooperative activities aimed at social value creation.

The concepts of social entrepreneurship and bricolage are strictly related to the traditional entrepreneurship's definition "to take into one's own hand" (Tapsell \& Woods, 2010, p. 536; see also Kickul, Griffiths \& Gundry, 2010; Kickul, Bacq \& Garud, 2013; Gundry, Kickul, Griffiths \& Bacq, 2011a). However, on the one hand, social entrepreneurs aim to exploit opportunities in an innovative way in order to address social needs and offer social transformations (Tan, Williams \& Tan, 2005; Mair \& Marti, 2006; Bacq \& Janssen, 2011; Starnawska, 2015; Zollo et al., 2016b; Zollo, Pellegrini, Faldetta \& Rialti, 2017b). On the other 
hand, bricoleurs seek to reorganize and recombine the already available and often neglected resources, by spontaneously applying them to address new opportunities and unpredicted challenges so as to create value (Ciborra, 1996; Baker et al., 2003; Garud \& Karnøe, 2003; Baker \& Nelson, 2005; Pellegrini et al., 2016; Zollo, Pellegrini \& Ciappei, 2016c; Zollo, Rialti, Ciappei \& Boccardi, 2017c). According to Gundry and colleagues (Gundry et al., 2011a; Gundry et al., 2011b), because social entrepreneurs have to constantly cope with resource-constrained environments, their ability to creatively and innovatively combine available resources to solve unexpected problems - which is referred to as bricolage - emerges as crucial in modern economic scenarios (see also Griffiths, Gundry \& Kickul, 2013). Consistently, recent scholars argue that entrepreneurial bricolage may be interpreted as the way modern entrepreneurs "catalyse" social innovation by effectively (1) combining available resources in an ingenious fashion and (2) entering new markets that are ignored by their competitors and seizing the latent profitable and attractive opportunities (see Desa \& Basu, 2013; Kickul, Bacq \& Garud, 2013; Bacq, Ofstein, Kickul \& Gundry, 2015). In this sense, it is possible to assess that the ephemeral social entrepreneurship bricolage strategies emerge when bricoleurs look for sustainable solutions to emergent social problems (Johannisson \& Olaison, 2007; Di Domenico et al., 2010; Desa, 2012).

Building on this rich literature background, the aim of this paper is to study the dynamics of social bricolage in the particular context of non-profit organizations involved in socio-health emergency and urgency activities. To analyze this phenomenon, we will use the philosophical perspective of deconstructionism. The deconstructionist approach, in fact, emerges as particularly adequate and appropriate to critically analyze the way bricoleurs implement their rearrangement of "whatever is at hand" in social contexts. In this sense, the next section illustrates how social bricolage may be interpreted using a destructionist approach.

\section{Social bricolage and deconstructionism}

As stated in the previous paragraphs, the act of "reorganizing the established and crafting the new" appropriately describes entrepreneurial activity (Steyaert \& Katz, 2004, p. 182). When such an activity is turned to social challenges, then social entrepreneurship arises (Tan et al., 2005; Mair \& Marti, 2006). Furthermore, we argued that the social entrepreneurship phenomenon is thoroughly suitable for the notion of bricolage, since it well describes the interpretative ability to reorganize and recombine resources so as to seize 'making do' opportunities in unpredicted challenges, thus creating innovative solutions (Baker et al., 2003; Garud \& Karnøe, 2003; Baker \& Nelson, 2005; Duymedjian \& Rüling, 2010). Due to the fact that the ultimate 
goal of this research is to analyse the recent notion of social bricolage, in this section, we will observe from an epistemological perspective how to unpack the concept in order to deeply understand its principles and dynamics. In this sense, the selected point of observation is the deconstructionist approach, an interpretative approach that has received scarce attention in the managerial literature except for few contributions (Cooper, 1989; Martin, 1990; Kilduff, 1993).

\section{The deconstructionist philosophical approach}

Originally, the expression deconstructionism referred to the post-modern philosophy of Jacques Derrida $(1976 ; 1978 ; 1988)$ who, in line with his complex and elitist language style, counterintuitively described it in this way: "Deconstruction does not exist somewhere, pure, proper, self-identical, outside of its inscriptions in conflictual and differentiated contexts; it "is" only what it does and what is done with it, there where it takes place (1988, p. 141)". Thus, what emerges from this definition is the epistemological function of deconstructionism, which consists of interpreting particular contexts, usually literary texts, characterized by semantic conflicts and differences of concepts that may reveal rhetorical dependencies (Derrida, 1976; Kilduff, 1993). At the beginning, deconstructionism was aimed at questioning the prevailing theory of structuralism (Lévi-Strauss, 1963), thus originating the so-called "structuralist controversy" (Derrida, 1966). In fact, deconstructionism, in its analysis of the Kantian phenomenological purposiveness of a determined structural system, focuses on contingent complexity that causes the structuring and deconstructing effects of a particular system, composed of interacting and conflicting events resulting in the evolution and dynamics of the structure (Pellegrini, Rialti, Ciappei, \& Zollo, forthcoming). In such a perspective, the expected, programmed and prearranged patterns of a structure's internal parts paradoxically constitute its boundaries, mainly because in unpredicted critical contingencies that particular structure cannot be used (Derrida, 1976; 1978).

Even though deconstructionism has been traditionally used in poststructuralist philosophy, such an analytic methodology has also interested management scholars who describe deconstructionism as "an analytic strategy that exposes, in a systematic way, multiple ways a text can be interpreted" (Martin, 1990, p. 340). Hence, in our effort to apply such a methodology to the entrepreneurial setting, the relevant interest refers to the strategic method of deconstructionism that systematically allows the interpretation of a particular social phenomenon. Because social entrepreneurship, and particularly social bricolage, are characterized by the systematic need to responsibly interpret social challenges so as to analytically find the most appropriate strategy (Tan 
et al., 2005; Steyart \& Katz, 2004; Bacq \& Janssen, 2011), deconstructionism seems extremely relevant in this scenario. Specifically, the importance of deconstructionism for social bricolage is in relation to the possibility of bringing about a 'dialogue' between external unpredicted contingencies and the prearranged patterns of a structured system's internal parts (Derrida, 1988; Duymedjian \& Rüling, 2010). Consequently, what Lévi-Strauss (1966) called 'repertoire', or stock of resources, may be interpreted in Derrida's terms as the phenomenological 'centre' of a unique and structured system composed of internal parts. Hence, we are led to argue that Derrida's deconstructionism can explain the assembling process of bricolage, recently defined as "a continual process of testing, permutation, and substitution of pre-existing objects" (Duymedjian \& Rüling, 2010, p. 138). Building on these theories, we may argue that social bricoleurs deconstruct prearranged patterns of available resources "at hand", and then they reinterpret the interactions and meaning of such resources, finally associating new functions with the existing repertoire to face critical and unexpected social events.

The deconstructionist approach can be analysed in sequential phases (Martin, 1990; Kilduff, 1993), namely: (1) individuate an emergent complex dichotomy among distinct elements of a system, focusing the attention on the suppressed or the excluded elements; (2) interpret the elements' contradictory dichotomy so to allow a vacant functional meaning of the excluded elements to arise; (3) fill such a semantic void by deconstructing the original system thanks to the iterative replacement of the elements' functional meaning; (4) temporally reconstruct the whole system of elements to implement a reinterpretation of the functional meaning, thus addressing the emergent complexity; (5) terminate such a deconstructionist process once the critical contingency has been addressed and the original status quo of the system is restored. To apply this theoretical construct to social entrepreneurship, and particularly to social bricolage, we begin with the first phase of deconstructionism, where unpredicted contingent social events create a critical contrast to the entrepreneurs' existing repertoire and its available resources. Because we stated that social bricoleurs refuse to "enact" thanks to their improvisation, creative, interpretative, and rearranging ability (Di Domenico et al., 2010; Desa, 2012), the second phase of deconstructionism is primarily concerned with a "making do" opportunity that social bricoleurs seize in the contingent complexity by reinterpreting the unused resources' function; this may give an innovative meaningful use to that resource. Then, social bricoleurs iteratively rearrange the available resources to ultimately create particular latent synergic relationships within the existing repertoire. In this way, the constraining gap between unexpected contingent events and a seemingly useless stock of resources is filled. It is in this phase 
that the social bricoleur becomes a "deconstructionist" in reinterpreting the functional process of resources' sub-groups. Consequently, the emergent threatening contingency becomes an improvised social opportunity thanks to the spontaneous reinterpretation of rearranged resources aimed at coping with unexpected social emergencies (Johannisson \& Olaison, 2007). Finally, social bricolage must stop the deconstructionist process and re-establish the normal functioning of the repertoire of resources, because what we may call bricolage deconstructionism has to come to an end once the critical event has been successfully managed (Martin, 1990; Kilduff, 1993).

In this paper, we interpret bricolage deconstructionism as an effective entrepreneurial solution to social emergencies. In the following section, we conceptualize a theoretical framework that highlights the different typologies of emergent social needs and the related entrepreneurial solutions.

\section{Social bricolage in a deconstructionist perspective}

Moving from the main characteristics of the deconstructionism approach, the main features of deconstructionism that may be applied to social bricolage refer to (1) the relations and the interactions between the resources' vacant functions; (2) the analytic reinterpretation of the resources' latent meaning; (3) the systematic reconstruction of hidden purposes, and (4) the innovative use of the resources' functions to creatively tackle unexpected social challenges by means of the repertoire of already existing resources (Martin, 1990; Kilduff, 1993). Because social bricolage deals with the complexity of the environmental and entrepreneurial scenario deriving from - (1) the seemingly inadequate repertoire of the available resources; (2) the dichotomy between unexpected social contingencies and such resources and, finally; (3) the bricoleur's ability to reassemble the available resources, thanks to their reinterpretation of their functional value - it can be argued that social bricolage may be interpreted as a particular type of deconstructionism. Precisely, deconstructionism enables social entrepreneurs to refuse "enacting," which is often due to unexpected emergencies, and therefore seizing, in such a contingent complexity, "making do" opportunities thanks to the latent function of resources "at hand" (Lévi-Strauss, 1966). It is clear that bricolage deconstructionism becomes particularly relevant in emergency, dynamic, nonlinear, and uncertain situations which typically depict the entrepreneurial and organizational scenario as a complex system (Stacey, 1995; Morel \& Ramanuajam, 1999; Pellegrini et al., 2016). The social and deconstructionist facets of bricolage may be considered as instances of complex system dynamics (Stacey, 1995), because bricolage specifically refers to the self-organization dynamic defined as the "spontaneous creation of complex structure as a result of the dynamics of the system" (Morel \& 
Ramanuajam, 1999, p. 280). The notions of spontaneity and self-organization are common to social bricolage, particularly when related to "emergency entrepreneurship," the latter being defined as a spontaneously coordinated and self-organized collective ephemeral effort made to cope with the challenges of environmental, social emergencies (Lanzara, 1983; Ciborra, 1996; Johannisson \& Olaison, 2007). As a result, temporary and reconstructed repertoires of resources arise from the social bricoleur's re-interpretative ability to address emergent and unexpected social issues. Hence, because of the deconstructionist perspective, social bricoleurs can innovatively interpret the variety of resources to reconfigure interactive relationships, thus revealing the already existing but latent synergic value of the enterprise's repertoire.

\section{A theoretical reassuming framework of entrepreneurial solutions to address emergent social needs}

In this paper, as addressed by our research question, we want to highlight how social bricolage may represent a suitable entrepreneurial solution to social needs. For this, we have tried to conceptualize a framework illustrating possible social bricolage behaviors capable of addressing the several typologies of social needs. The proposed behavior will also be explored in relation to several kinds of solutions to the problem (see Figure 1).

\section{Absolute Social Bricolage}

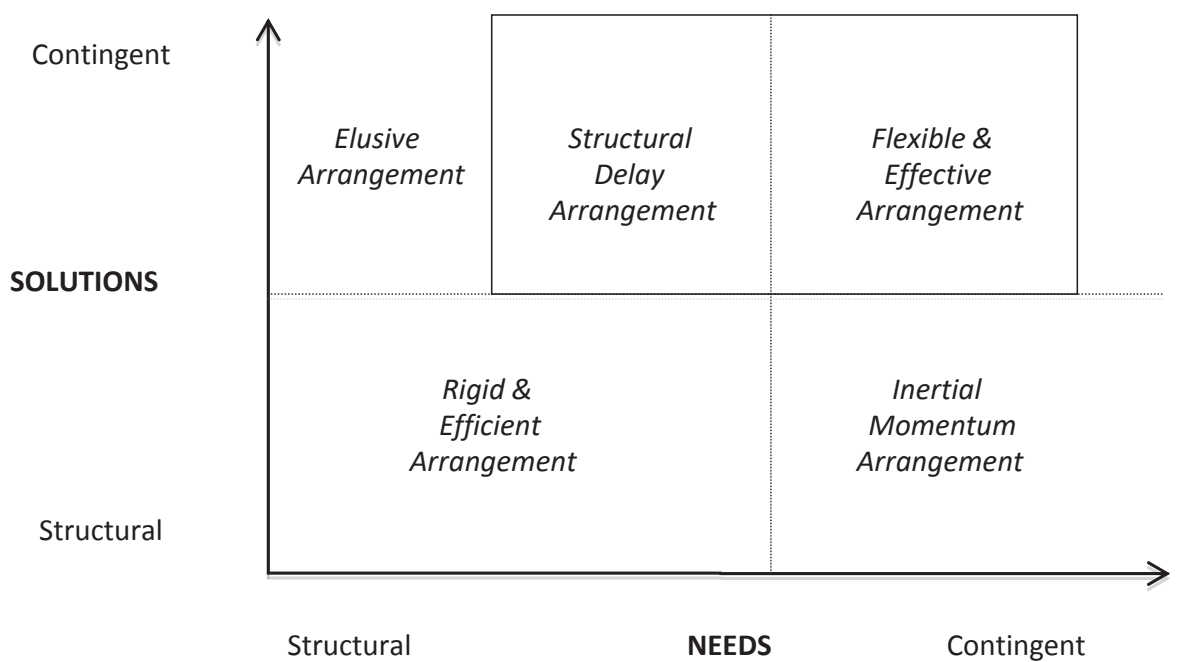

Figure 1. A theoretical framework of social bricolage 
Building on Lévi-Strauss (1966), we have applied the opposition between ,structure' and ,event' in relation to social needs and entrepreneurial solutions. We choose to use the notion of 'contingency' instead of 'event' because the former refers to a more general conceptual framework while the latter has been predominantly developed within the marketing communication literature. However, the notion of 'contingency' is almost the equivalent of event since we refer to contingent social needs that are unexpected and improvised, and require immediate solutions. Moreover, contingent needs do not require structural change but ephemeral and ad hoc interventions. Hence, in order to respond to contingent social needs, resources' redundancy is more important than efficiency.

Our first theoretical classification, which is represented in the horizontal axis, refers to the typologies of social needs that entrepreneurs or institutions have to cope with. It is possible to classify social needs as structural or contingent. Structural social needs have to be satisfied in the long term and require efficient solutions in order to guarantee sustainability, while, contingent social needs can be defined as temporary, unpredictable, and extraordinary in their manifestation.

Our second theoretical classification, represented on the vertical axis, refers to the typologies of entrepreneurial and institutional solutions to social needs. Two types of solutions have been identified - structural and contingent. The structural solutions are efficient and strategic, and last longterm thanks to routine processes, organizational consolidation, and balanced development resulting in qualitative growth. On the other hand, contingent solutions are temporary, unpredicted, and immediate solutions that guarantee entrepreneurial resilience to urgent criticalities. For these solutions, the main features of bricolage are more important than structural efficiency (Baker et al., 2003; Garud \& Karnøe, 2003; Baker \& Nelson, 2005). Indeed, adaptability, improvisation, and resilience are evidently more relevant when social entrepreneurs have to cope with unexpected social problem or emergencies.

At this point, we have conceptualized four possible arrangements between social needs and the corresponding solutions. Mostly, according to our framework, structural social needs require structural solutions, whereas contingent social needs require contingent solutions. Nevertheless, we also analyze criticalities in relation to mixed solutions. The possible social bricolage behaviors to address both structural and contingent needs are the following: 1) Rigid Efficient Arrangement: Firstly, when structural solutions address structural needs, we conceptualize an arrangement that pursues efficiency, permanence, focalization, and stability. This kind of response strategy is possible due to the aforementioned processes of routines, consolidation, and balanced development typical of structural responses 
(Stacey, 1995; Morel \& Ramanuajam, 1999; Johannisson \& Olaison, 2007). We interpret such an area as a 'rigid and efficient arrangement.'

2) Flexible and Effective Arrangement: Secondly, when contingent entrepreneurial solutions address contingent social needs, we conceptualize an arrangement that aims at efficacy and effectiveness, and transitory and improvised processes characterized by a 'ritualized ingenuity' (Lévi-Strauss 1966; Duymedjian \& Rüling 2010). In this area, entrepreneurial solutions refer to effective interventions on external contingencies in order to seize 'making do' opportunities and avoid the threat of 'refusal to enact', although the outcomes will not be strictly 'engineered' (Ciborra, 1996). We interpret such an area as a 'flexible and effective arrangement' and it typically refers to the Absolute Social Bricolage area of our framework.

3) Inertial Momentum Arrangement: Thirdly, when structural solutions address contingent social needs, we conceptualize an arrangement that, notwithstanding the actual new and different contingency, pursues efficiency through unnecessary focalization and outcomes, permanency of obsolete structures, and inappropriate stability (Lévi-Strauss, 1966). We interpret such an area as an 'inertial momentum arrangement,' referring to the inertial activity of the structure, and also to external contingencies that cause functional inappropriateness (Zollo et al., 2017c).

4) Elusive Arrangement and Structural Delay Arrangement: Finally, when contingent entrepreneurial solutions address structural social needs, we conceptualize an arrangement that aims at partial, improvised, and pro tempore solutions that postpone the appropriate, but temporarily unavailable, responsibility of structural solutions (Baker \& Nelson, 2005). In such an area, it is possible to individuate two different arrangements elusive and structural delay. The elusive arrangement refers to when the solution equals elusion so as to shift on to others the problem of facing social needs. The latter refers to 'suspension bridge' solutions addressed to new structural needs where the solutions represent a strictly effective response to new social needs that only in their nascent phase may be interpreted as 'events' (Baker et al., 2003; Garud \& Karnøe, 2003). Nevertheless, the 'structural delay arrangement' behavior has been deemed as belonging to the Absolute Social Bricolage area similar to the 'Flexible and Effective Arrangement.'

The nascent phase of a new structure is different from the ephemeral contingency, mainly because it will last in the long term, and this phase may be considered as an event. In such a context, we stress the difference between contingency and event. While the former is temporary, the event may be referred to as a structural need. Hence, we argue that an emergent need is both the need of a contingency and a structure in its nascent phase. We define the notion of 'emergent' as a social need that arises unexpectedly 
and calls for a prompt solution, due to its ephemeral feature or its nascent phase that will become structural.

In the nascent phase, contingent and structural needs show a strong connotation of 'event' and thus require the bricolage arrangement for the appropriate entrepreneurial solutions. In our conceptual framework, social bricolage represents a contingent solution to contingent social needs and a pro tempore solution to structural social needs in the nascent phase (Stacey, 1995; Morel \& Ramanuajam, 1999). This latter case relates to a 'bridge' solution that initiates a future structural solution in marked contrast to the elusive solutions. Consequently, social bricolage's solutions seem appropriate for the 'flexible and effective arrangement' and the 'structural delay arrangement' as well. We define social bricoleurs coping with contingent social needs as 'deconstructionist' because of their temporary perspective focused on the resources' latent meaning and vacant functionality. On the other hand, social bricoleurs providing contingent solutions to structural social needs in the nascent phase are defined as 'constructionists' because of their ability to individuate the ephemeral determinants of nascent structures that will arise in the future.

\section{METHODOLOGY, DATA COLLECTION AND RESEARCH SETTING}

Recently, entrepreneurship research has emphasized the importance of deepening the level of analysis of the social entrepreneurship phenomenon (Chell, 2007; Bacq \& Janssen, 2011). The main reason for this is the scarce quantitative and qualitative analyses of social entrepreneurship due to the relatively recent nature of such a phenomenon (Perrini, Vurro \& Costanzo, 2010). This is particularly evident in recent research on social bricolage ( $\mathrm{Di}$ Domenico et al., 2010; Desa, 2012).

\section{Methodology}

In order to fill the aforementioned literature gap, a longitudinal case study approach has been selected (Van de Ven \& Huber, 1990; Yin, 2013). This methodology allows both the theoretical comprehension of a littleknown phenomenon (Yin, 2013) and the generalization of the findings (Eisenhardt, 1989). Qualitative research is suitable when information is scant about a phenomenon (Eisenhardt, 1989) and when the aim is to develop ideas from the data in order to iteratively link them to theoretical perspectives (Anderson, Sarah \& Jack, 2010).

We started from existing social entrepreneurship and social bricolage theory in order to develop a theoretical framework aimed at guiding the 
empirical analysis (Perrini, Vurro \& Costanzo, 2010; Yin, 2013). To show different typologies of emergencies and related possible solutions, we investigated the consistency between the pre-developed theoretical framework and the evidence emerging from the case study, thus highlighting the advantages of social bricolage. Given the explorative nature of our study and the scarcity of research on social bricolage, we searched for a context that could represent an extreme case (Pettigrew, 1990). In fact, extreme cases identify possible theoretical paradigms usable prevalently in similar contexts and comparable future researches (Perrini et al., 2010). Therefore, the case of one of the ancient non-profit organizations (NPOs) in the world, the "Venerabile Arciconfraternita della Misericordia di Firenze" (Confraternity of Mercy of Florence), represents the empirical setting for the chosen study. The significant historical importance of 'Venerabile Arciconfraternita della Misericordia di Firenze' (hereafter Misericordia) gives us a unique opportunity to study social entrepreneurship and social bricolage. Misericordia is a private NPO pursuing social goals and can be classified as a social entrepreneurial venture according to recent literature (Defourny \& Nyssen, 2010). Misericordia deals with a wide variety of social emergencies every day, which makes it a suitable case study in order to analyze different typologies of emergencies, possible social entrepreneurial solutions, and social bricolage.

The Misericordia of Florence is the oldest Tuscan Voluntary Association dating back to the Thirteenth Century (1244), based in Florence (Region of Tuscany, Italy). Since its foundation, Misericordia has been dedicating itself to numerous charitable works, i.e., the transportation of the sick to hospitals, care of the debilitated and indisposed, burial of the poorest people, and social assistance for needy and poor families. Misericordia has been involved in providing crucial support since the severe plagues that struck Florence in 1325 and for transporting the sick to hospitals and conducting funerals since 1630. Secondly, Misericordia provided assistance during World War II, when its ambulances were indispensable means of transportation and rescue of wounded soldiers. More recently, Misericordia offered crucial help during the flood of 1966 that struck Florence. All this reflects the great importance and utmost usefulness of the historical charity, the hard work, the generosity of Misericordia, and the continuity of such a fundamental societal service.

Nowadays Misericordia is engaged in numerous activities: an ambulance service; a home care for the elderly and the sick; transportation of the sick and donation of blood; interest-free loans of medical equipment; and the organization of funerals and transport of the deceased. Moreover, it has established a foundation to help people with intellectual disabilities, residences for the care of the elderly, and clinics for medical examination and instrumental diagnostics. Finally, Misericordia is able to operate the services of 
Civil Protection and collaborate with other public and voluntary governmental structures, in order to respond to regional or national emergencies. In this way, Misericordia reflects the recent definition of social entrepreneurship (Defourny \& Nyssen, 2010). The specificity of Misericordia consists in its intervention in social emergencies, hence representing a valid case study for social entrepreneurship and particularly for social bricolage. Misericordia faces everyday emergencies, and show adaptability, improvisation, and resilience both at an individual and a structural level (Lévi-Strauss, 1966).

Due to its history and its long-standing activities, Misericordia represents a suitable extreme case to explore the phenomenon of bricolage in social entrepreneurship. Specifically, on the one hand, Misericordia is one of the most ancient social entrepreneurial ventures still in existence and has been operating continuously since 1244 , and in addition, while it has adapted to the changing environment over its long history, it has shown a high level of resilience by never changing its mission. On the other hand, during its long history Misericordia has faced emerging unexpected social needs many times. In this sense, it has also reacted frequently to emergent social needs as a bricoleur rearranging existing resources in an unusual way. Moving on from this, we have considered Misericordia as an extreme case. In particular, the lessons from the analysis of Misericordia's case may also be useful for understanding the dynamics of younger social entrepreneurial ventures and their reactions to emerging social needs.

\section{Data}

According to the literature on extreme longitudinal case studies (Eisenhardt, 1989; Pettigrew, 1990; Van de Ven \& Huber, 1990), we used three categories of sources. In particular, we have selected the three following ones:

1) Internal magazines, annual reports and other external communication tools. Building on Darke and colleagues' research (Darke, Shanks \& Broadbent, 1998), we have selected internal magazines and reports as our preferred source of information. In particular, we have consulted the last ten digitalized volumes of the 'San Sebastiano Journal,' the monthly published by Misericordia in order to inform its stakeholders. Hence, we have analyzed the last ten years of public communication and 16 annual reports (i.e., Misericordia's Sustainability Report), specifically every one produced by Misericordia's accountants since 2000, and the NPO's corporate web site (www. misericordia.firenze.it). Moreover, we have also considered several articles published in a number of Italian Newspaper such as 'La Nazione','La Repubblica' and 'Il Corriere della Sera' and the sections regarding the events concerning the city of Florence.

2) Corporate chronicles and archival material. Museum of Misericordia, located in Florence contains more than seven centuries of history, and 
a historical archive containing about 4000 documents dating from the Fourteenth Century. We have consulted this archival material to gather data on the historical actions of Misericordia and, specifically, an insight on their decision processes and past strategies. The analysis of archival material is in line with best practices for case study methodology (Eisenhardt, 1989).

3) Semi-structured interviews. In order to gather additional data, 24 semistructured interviews were conducted: with the president of Misericordia (1 interview), the general director (3 interviews), two divisional directors ( 5 interviews in total) and fifteen volunteers (15 interviews in total). The interviews were conducted between January 2013 and May 2015. Each interview lasted from one to two hours and all of them were recorded. In total, we have gathered 35 hours of semi-structured interviews that have been transcribed into a 98-page text. To collect data, semi-structured interviews were selected as they allow a better understanding of the dynamics of a phenomenon through discussion with experienced individuals (Wengraf, 2001; Yin, 2013). Moreover, since they are not structured, it is possible to deviate from the original program and ask the experts for more information.

The longitudinal case study was conducted in several stages. Firstly, a preliminary analysis (Perrini et al., 2010) enabled us to reconstruct Misericordia's chronology, from its archival and historical data, in order to better understand its ancient origins, modern developments, and the historical pivotal events. For ultimate data triangulation (Eisenhardt, 1989), the archival and historical data have been compared with the results of the semi-structured interviews and the data from Misericordia's Sustainability Reports. After this preliminary data exploration process, aimed at delineating Misericordia's historical evolution, we investigated the NPO's main interventions in social emergencies that have hit Tuscany. Our aim was to understand the different solutions addressed to social emergencies, in order to analyze the existence of social bricolage in Misericordia.

\section{RESULTS}

Based on the iterative comparison between literature on social bricolage and the empirical findings resulting from the case study, we provide an analysis of the main entrepreneurial and institutional solutions to social needs. Particularly, we have focused on identifying whether Misericordia has applied the four strategies delineated in the proposed framework by looking at examples of social need where such intervention was needed. In this sense, the findings of our research deal with the confirmation of our framework. 
Rigid and efficient arrangement: The institution of 118 national-service

The case study of Misericordia has shown that when structural needs emerge, it is appropriate to implement structural solutions, thus guaranteeing efficiency in the long term (Ciborra, 1996; Johannisson \& Olaison, 2007). This is particularly evident in the creation of the 118 national-service in 1991 by the Italian Governmental Institutions, which refer to the central units of coordination of emergency-urgency societal needs. In particular, in 1991, after the 1990 FIFA World Cup hosted by Italy, the need emerged to centralize all the sanitary emergency services under one umbrella in order to avoid overlapping and wasting of resource during emergencies. Then the Italian government, with law 76 of 31/03/1992, urged all the NPOs operating in emergency services to adapt to new service standards or relinquish their authorization to operate. Before this service was established, each NPO autonomously coordinated the emergency-urgency activities, which resulted, as assessed, in several inefficiencies in time and cost, i.e., the duplication of volunteers and ambulances for a single service, or NPOs' interventions in distant regional areas that could have been addressed by more local NPOs. In order to improve such a decentralized system, a national conjoined system for emergency-urgency social services has been established which is composed of regional NPOs including Misericordia. In this sense, an important element of the deconstructionist perspective has been applied, namely by reinterpreting possible interactions and relations among available regional socio-healthcare actors - which are NPOs and Governmental Institutions - and their conjoint vacant functions (see Martin, 1990; Kilduff, 1993). In this case, the institutional solution has been structural and efficient for a particular stable, generalized, and recurring social need (Zollo et al., 2017c). In these circumstances, a bricolage solution might be inappropriate because the problem involved recurring routines and due to the structural nature of the need (Kilduff, 1993; Johannisson \& Olaison, 2007). Hence, in this situation, Misericordia adapted to the need to develop a rigid structure in order to continue to operate in emergency sanitary services. This is coherent with the hypothesized rigid and efficient arrangement solution.

Flexible and effective arrangement: Evidence from the Florence Flood of 1966 This area refers to contingent social needs that are matched with contingent solutions, an example of which can be represented by Misericordia's intervention in the dramatic flood that hit the city of Florence on November 4, 1966. After several days of uninterrupted bad weather, the river Arno unexpectedly flooded the city. The damage to the city and the Misericordia headquarter was enormous and required the NPO to rearrange its scarce existing resources to cope with the emergency. 
In this case, the social need was contingent, i.e., it was unpredicted and temporary, even if particularly serious. Misericordia implemented a social bricolage solution that was, firstly, immediate and spontaneous for the inhabitants (Duymedjian \& Rüling, 2010); secondly, it was transitory and ephemeral since no organized structure was established (Lévi-Strauss, 1966); thirdly, it was improvised and collective because Misericordia succeeded in deconstructing the community's social relationships, thus activating the Florentines' workforce regardless of their professional occupation and social class (Garud \& Karnøe, 2003); finally, the solution recalled the notion of 'ritualized ingenuity' since it was extremely important to create solidarity networks based on momentary emotionality (Duymedjian \& Rüling, 2010). We define this social bricolage solution as 'deconstructionist' by examining its process (Derrida, 1966; 1976). (1) Initially, an emergent dichotomy between the community social structure and the relative destructive external contingency was analytically individuated; (2) Secondly, Misericordia succeeded in bringing about the population's latent solidarity and its awareness of the problems and difficulties of the time that were endangering its own survival and the persistence of the cultural patrimony; (3) Then, the ordinary social structure was deconstructed by mobilitating the 'existing resources', i.e., the citizens of Florence, and assigning normally inappropriate duties, tasks, and functions to them; actually, citizens at first seemed inadequate to cope with the flood, but thanks to Misericordia's ability to reassemble volunteers' available resources - such as reciprocity, a willingness to collaborate and donate, etc....(see Baran, 2013; Zollo, Faldetta, Pellegrini \& Ciappei, forthcoming) - such a "repertoire" of critical human resources emerged as crucial in dealing with the natural disaster; (4) Consequently, Misericordia was able to reconstruct a solidarity network resulting ultimately in the creation of essential social existence and survival conditions; (5) Finally, once the external critical contingency had been resolved, the bricolage deconstructionist approach was terminated (Derrida, 1976; Martin, 1990; Kilduff, 1993), thus restoring the ordinary social structure of the city. Therefore, Misericordia acted as a bricoleur. In fact, the NPO preferred to act immediately by rearranging the scarce resources to cope with an unexpected social need.

\section{Inertial momentum arrangement: The Genoa Flood of 2014}

During the night of October 10, 2014, the Sturla River flooded some zones of Genoa city center. On the following day, even the Bisagno River, whose stream bed was inappropriately used as a parking lot, flooded. The flood claimed one death, but also caused damage to the city, and in particular, the majority of the centre was covered by mud and the streets were full of 
rubble. The day after the flood, Misericordia was asked by the government to participate in the rescue efforts.

This case of Misericordia highlights an example of an 'inertial momentum arrangement' providing a structural solution to a contingent social need (Lévi-Strauss, 1966; Garud \& Karnøe, 2003) but, in this instance, no social bricolage solution was provided by NPOs, including Misericordia, since the Governmental Institutions decided to intervene by mobilising the 'Protezione Civile' (Civil Defence). This rigid and bureaucratic solution predominantly made use of internal structures of the Protezione Civile, thus resulting in an insufficient intervention because the contingency of the event had not been recognized. A social bricolage solution, with the activation of a solidarity network and a shared participation, as illustrated previously in the Florence flood, might have been more effective (Martin, 1990). The bureaucratic implementation of the Protezione Civile resulted in an ineffectively programmed solution, thus voluntarily avoiding the redundancy of volunteers, people and citizens (Kilduff, 1993; Ciborra, 1996). Hence, redundancy becomes (Baker et al., 2003; Di Domenico et al., 2010), in such a context of contingent social needs, more important than specificity, focusing, and efficiency. Also, in this case, Misericordia's ability to reassemble the "human" available resources - such as citizens and volunteers - may be interpreted as an effective type of deconstructionism thanks to the NPO's reinterpretation of resources' functional value (Derrida, 1976; Martin, 1990; Kilduff, 1993).

\section{Structural delay arrangement and elusive arrangement, some insights on the current evolution of Misericordia health services}

In a context characterized by structural social needs and contingent solutions, there are two possible arrangements, namely the 'structural delay arrangement' and the 'elusive arrangement.' For both arrangements, an example that emerged from the case study refers to the 'reverse subsidiarity' related to the dismantlement of Tuscany welfare (Zollo et al., 2016a; b). Subsidiarity refers to the local institutional network that provides services to the community since Governmental Institutions have to intervene only when the organized community, i.e., the Third Sector, cannot. However, in case of government failure, the Third Sector which is composed of NPOs including Misericordia is able to integrate from the bottom the deficiencies of the State (Zollo et al., 2016b). For example, Misericordia filled socio-health public voids thanks to (a) medical and diagnostic interventions at low prices in comparison with regional tickets; (b) opening of information points aimed at therapeutic and clinic treatment for people in a confused state of mind; (c) mobile medical clinics on NPOs' ambulances for socio-health services; (d) creation 
of touristic emergency medical services; (e) few interventions of civil defence in small environmental contingencies. Hence, the social solution proposed by Misericordia constitutes a contingent solution to structural social needs that can be interpreted as a pro tempore stop-gap measure in comparison with the forthcoming National Health Service's reconstruction (Lévi-Strauss, 1966; Garud \& Karnøe, 2003). The attitude of the Region of Tuscany represents an 'elusive arrangement' in that the institutional measures are not able to satisfy the real needs of citizens or otherwise they represent inappropriate bureaucratic solutions (Zollo et al., 2017c). On the contrary, the temporary intervention of Misericordia is an example of 'structural delay arrangement.' In effect, the solution provided by the NPO is a social bricolage solution to structural social needs in their nascent phase (Kilduff, 1993; Johannisson \& Olaison, 2007). Misericordia activates the repertoire of improvised social relationships by rearranging the available existing resources, thus revealing the resilient aspect of the Third Sector in the presence of social contingencies (Derrida, 1976). We define this type of social bricolage as 'constructionist' - which may be interpreted as the final outcome of the aforementioned deconstructionist approach - because the relatively autonomous solutions of Governmental Institutions are redefining from the bottom an activation of the available existing resources that in the future could result in integrated socio-health solutions between the public sector and Third Sector (Zollo et al., 2017b; c).

\section{CONCLUSIONS, IMPLICATIONS AND LIMITATIONS}

The present research contributes to the stream of literature on social entrepreneurship and bricolage (Chell, 2007; Bacq \& Janssen, 2011). In this sense, our findings provide systematization in a framework of the main bricoleur solutions that social entrepreneurial ventures, such as Misericordia, may select to address an emerging social need (Johannisson \& Olaison, 2007). Specifically, while the existing literature contributes by highlighting the importance of social entrepreneurial ventures adopting bricolage solutions, this research digs deeper into the phenomenon by providing some relevant insights. As an example, our research firstly provides a framework for assessing which kind of solution (more bricoleur oriented or more structured) is more appropriate to address emerging social needs. Secondly, the present research is among the first to be using deconstructionism (Derrida, 1966; 1796) as a lens to better understand how a bricoleur reaction may be implemented by a social entrepreneurial venture. In particular, it highlighted how following a deconstructionist 
approach enables a social entrepreneurial venture to refuse "enacting", which is often related with unexpected emergencies, and how seizing, in such a contingent complexity, "making do" opportunities exploits unusual function of resources "at hand" (Lévi-Strauss, 1966). Hence, the case study of Misericordia of Florence confirms that social bricolage is a suitable solution when adaptability, improvisation, and resilience are more important than structural efficiency (Baker et al., 2003; Di Domenico et al., 2010). In effect, in social bricolage, the redundancy of resources is more significant than specificity and efficiency. As a consequence, as the principal managerial implication we may argue that social bricolage is an entrepreneurial opportunity to address emergent social needs. In our perspective, emergent social needs are both contingent and structural in their nascent phase, as illustrated previously in our theoretical framework. In contingent social needs, a social bricoleur is able to improvise the most effective, immediate, and flexible solution, rearranging the available repertoire of existing resources, and finally refusing to enact in order to find a solution to social contingencies.

The social bricolage approach is also a pro tempore stop-gap measure for structural needs in their nascent phase (Lévi-Strauss, 1966; Garud \& Karnøe, 2003). In this case, social bricolage provides an effective solution to structural social needs that in their ascent phase can be interpreted as "events" (Lévi-Strauss, 1966). Such a solution is temporary and constitutes a "suspension bridge" between the old structure and the new structure that will be created. However, the bricolage solutions to structural needs do not guarantee in the long term the necessary efficiency. Secondly, we identify the emergent social needs as a syncretic category that embraces both contingent needs and structural needs in their nascent phase (Garud $\&$ Karnøe, 2003). These needs are similar to Lévi-Strauss's concept of "event" and are coherent with a social bricolage solution. Thirdly, building on Derrida's deconstructionism, we identify two types of possible social bricolage interventions for the emergent social needs. On the one hand, in order to cope with contingent social needs, social bricoleurs may intervene according to a deconstructionist approach. In this case, because the contingent emergency deconstructs the environmental context, social bricoleurs have to deconstruct their repertoire of available resources in order to create a fitting dialogue with the context. Hence, the most important phases refer to the initial identification of the resources' vacant functions in relation to the external contingencies; then, rediscover the latent potential of available resources by reinterpreting their functional meaning; after such a de-specializing activity, social bricoleurs systematically and temporarily reconstruct the hidden purposes of the existing resources 
(Lévi-Strauss, 1966; Di Domenico et al., 2010). In such a deconstructionist approach the social bricoleur also realizes a reconstructionist activity since they recombine the existing repertoire so as to innovatively use the available resources. However, the main activity is the deconstruction of the stock of resources, thus addressing the environmental deconstruction determined by the external contingency, which may cause the destruction of the status quo.

On the other hand, when the emergent need is structural, even though it is in its nascent phase, social bricoleurs have to implement a constructionist approach. In this case, the bricolage solution exploits both improvisation and adaptability, but the main activity refers to the creation of a temporary bridge toward a new structure. Social bricolage is a pro tempore stop-gap measure that does not exclude the necessity of a consecutive structural solution thus guaranteeing sustainability and efficiency in the long term. Finally, in relation to regional development, our study highlights two types of positive contributions of social bricolage. First, in the case of contingent social needs, an external contingency destroys the social structure and the regional developmental process. So, social bricoleurs do not explicitly trigger the developmental process, but they contrast the entropy of the system potentially resulting from the contingency. Second, in the case of structural social needs in the nascent phase, social bricoleurs activate a structural developmental process by constructing a pro tempore bridge between the old structure and the new one (Baker \& Nelson, 2005).

In short, therefore, apart from the developed framework, the research contribution is related to providing an original interpretation of the bricolage in social entrepreneurship phenomenon thanks to deconstructionism. Due to the results of our empirical analysis, it has been possible to answer the question highlighted in the first section of our research. Based on the case study analysis of Misericordia of Florence, we can distinguish four possible entrepreneurial and institutional solutions to social needs. Specifically, it has been possible to assess the social bricolage solution as a significant opportunity within the social entrepreneurship field, particularly to address emergent social needs (Garud \& Karnøe, 2003). We refer to the efficiency showed by the bricolage solution proposed by Misericordia to overcome the social needs deriving from the 1966 Florence's flood and the almost ineffective solution to Genoa's 2014 flood. Moreover, due to the results of our research, it has been possible to explore the proposed framework through the identification of several kinds of response strategies, which are coherent with the ones proposed in our framework.

In spite of the findings, however, the research has several limitations. In particular, firstly the research is limited regarding the selected methodology

Social Entrepreneurship and Social Enterprise Phenomenon: Antecedents, Processes, Impact across Cultures and Contexts

Marzena Starnawska and Agnieszka Brzozowska (Eds.) 
and the analysis of a single case study. In fact, our paper has evidently many limitations typically related to case study research (Eisenhardt, 1989; Yin, 2013). Secondly, as a consequence of the selected methodology, the results of our explorative research may only be considered preliminary and not fully generalizable. Specifically, the results are valid only for the selected case. Finally, our research can only be considered exploratory research and other research is required to validate our results again. Therefore, future research is needed in order to empirically test our results and further explore the assumption that bricolage may be a significant opportunity for social entrepreneurs in order to address emergent social needs.

\section{References}

Alvarez, S.A., \& Barney, J.B. (2007). Discovery and creation: Alternative theories of entrepreneurial action. Strategic Entrepreneurship Journal, 1(1-2), 11-26.

Anderson, A.R., Drakopolou-Dodd, S., \& Jack, S. (2010). Network practices and entrepreneurial growth. Scandinavian Journal of Management, 26(2), 121-133.

Anderson, A.R., \& Starnawska, M. (2008). Research practices in entrepreneurship: Problems of definition, description and meaning. The International Journal of Entrepreneurship and Innovation, 9(4), 221-230.

Andries, P., Debackere, K., \& Looy, B. (2013). Simultaneous experimentation as a learning strategy: Business model development under uncertainty. Strategic Entrepreneurship Journal, 7(4), 288-310.

Arend, R. J., Sarooghi, H., \& Burkemper, A. (2015). Effectuation as ineffectual? Applying the $3 \mathrm{E}$ theory-assessment framework to a proposed new theory of entrepreneurship. Academy of Management Review, 40(4), 630-651.

Bacq, S., \& Janssen, F. (2011). The multiple faces of social entrepreneurship: A review of definitional issues based on geographical and thematic criteria. Entrepreneurship and Regional Development, 23(5-6), 373-403.

Bacq, S., Ofstein, L.F., Kickul, J.R., \& Gundry, L.K. (2015). Bricolage in social entrepreneurship: How creative resource mobilization fosters greater social impact. The International Journal of Entrepreneurship and Innovation, 16(4), 283-289.

Baker, T., Miner, A.S., \& Eesley, D.T. (2003). Improvising firms: Bricolage, account giving and improvisational competencies in the founding process. Research Policy, 32(2), 255-276.

Baker, T., \& Nelson, R. (2005). Creating something from nothing: Resource construction through entrepreneurial bricolage. Administrative Science Quarterly, 50(3), 329-366.

Baran, M. (2013). The modelling process of the materials management system in a manufacturing company based on the system dynamics method. Journal of Entrepreneurship, Management \& Innovation, 9(2), 79-96. 
Brzozowska, A., Glinka, B., \& Postuła, A. (2014). Role of university in creating entrepreneurial attitudes. Horyzonty Wychowania, 13(26), 51-71.

Campos, H.M., Alvarado Acuña, L.S., de la Parra, J.P.N., \& Aguilar Valenzuela, F.A. (2013). Entrepreneurial orientation in Mexican microenterprises. Journal of Entrepreneurship, Management \& Innovation, 9(3), 5-20.

Ciappei, C., Laudano, M.C., Zollo, L., \& Rialti, R. (2016). Evaluating the quality of entrepreneurial education analysing its ability to increase entrepreneurial attitude and intent of students. 19th Toulon-Verona International Conference (5-6 September). Spain: University of Huelva.

Ciborra, C.U. (1996). The platform organization: Recombining strategies, structures, and surprises. Organization Science, 7(2), 103-118.

Chell, E. (2007). Social enterprise and entrepreneurship towards a convergent theory of the entrepreneurial process. International Small Business Journal, 25(1), 5-26.

Cooper, R. (1989). Modernism, post modernism and organizational analysis 3: The contribution of Jacques Derrida. Organization Studies, 10(4), 479-502.

Darke, P., Shanks, G., \& Broadbent, M. (1998). Successfully completing case study research: Combining rigour, relevance and pragmatism. Information Systems Journal, 8(4), 273-289.

Defourny, J., \& Nyssens, M. (2010). Conceptions of social enterprise and social entrepreneurship in Europe and the United States: Convergences and divergences. Journal of Social Entrepreneurship, 1(1), 32-53.

Derrida, J. (1966). Structure, sign, and play in the discourse of the human sciences. In R. Macksey \& E. Donato (Eds.), The Structuralist Controversy (pp. 247-272). Baltimore, MD: Johns Hopkins University Press.

Derrida, J. (1976). Of Grammatology. Baltimore, MD: Johns Hopkins University Press.

Derrida, J. (1978). Writing and Difference. Chicago, IL: University of Chicago Press.

Derrida, J. (1988). Limited Inc. Evanston, IL: Northwestern University Press.

Desa, G. (2012). Resource mobilization in international social entrepreneurship: Bricolage as a mechanism of institutional transformation. Entrepreneurship Theory and Practice, 36(4), 727-751.

Desa, G., \& Basu, S. (2013). Optimization or bricolage? Overcoming resource constraints in global social entrepreneurship. Strategic Entrepreneurship Journal, 7(1), 26-49.

Di Domenico, M., Haugh, H., \& Tracey, P. (2010). Social bricolage: Theorizing social value creation in social enterprises. Entrepreneurship Theory and Practice, 34(4), 681-703.

Duymedjian, R., \& Rüling, C.C. (2010). Towards a foundation of bricolage in organization and management theory. Organization Studies, 31(2), 133-151.

Eisenhardt, K.M. (1989). Building theories from case study research. Academy of Management Review, 14(4), 532-550. 
Fisher, G. (2012). Effectuation, causation, and bricolage: A behavioral comparison of emerging theories in entrepreneurship research. Entrepreneurship Theory and Practice, 36(5), 1019-1051.

Garba, A.S., Djafar, F., \& Mansor, S.A. (2013). Evidence of opportunity and necessity driven entrepreneurship in Nigeria. Journal of Entrepreneurship, Management \& Innovation, 9(3), 57-78.

Gartner, W. B. (1990). What are we talking about when we talk about entrepreneurship? Journal of Business Venturing, 5(1), 15-28.

Garud, R., \& Karnoe, P. (2003). Bricolage versus breakthrough: Distributed and embedded agency in technology entrepreneurship. Research Policy, 32(2), 277-300.

Garud, R., \& Giuliani, A.P. (2013). A narrative perspective on entrepreneurial opportunities. Academy of Management Review, 38(1), 157-160.

Griffiths, M.D., Gundry, L.K., \& Kickul, J.R. (2013). The socio-political, economic, and cultural determinants of social entrepreneurship activity: An empirical examination. Journal of Small Business and Enterprise Development, 20(2), 341-357.

Gundry, L.K., Kickul, J.R., Griffiths, M.D., \& Bacq, S.C. (2011a). Creating social change out of nothing: The role of entrepreneurial bricolage in social entrepreneurs' catalytic innovations. In J. Katz \& A.C. Colbert (Eds.), Advances in Entrepreneurship, Firm Emergence and Growth (pp. 1-24). Bingley, UK: Emerald Group Publishing Limited.

Gundry, L.K., Kickul, J.R., Griffiths, M.D., \& Bacq, S.C. (2011b). Entrepreneurial bricolage and innovation ecology: Precursors to social innovation? Frontiers of Entrepreneurship Research, 31(19), 3.

Johannisson, B., \& Olaison, L. (2007). The moment of truth - Reconstructing entrepreneurship and social capital in the eye of the storm. Review of Social Economy, LXV(1), 55-78.

Katila, R., \& Shane, S. (2005). When does lack of resources make new firms innovative? Academy of Management Journal, 48(5), 814-829.

Kickul, J., Griffiths, M.D., \& Gundry, L. (2010). Innovating for Social Impact: Is Bricolage the Catalyst for Change. Handbook of Research on Social Entrepreneurship. Cheltenham, UK: Edward Elgar.

Kickul, J., Bacq, S., \& Garud, N. (2013). Catalyzing social innovation: Is entrepreneurial bricolage always good? (summary). Frontiers of Entrepreneurship Research, 33(18), 6.

Kilduff, M. (1993). Deconstructing organizations. Academy of Management Review, 18(1), 13-31.

Lanzara, G.F. (1983). Ephemeral organizations in extreme environments: Emergence, strategy, extinction. Journal of Management Studies, 20(1), 71-95.

Lévi-Strauss, C., Jacobson, C., \& Schoepf, B.G. (1963). Structural Anthropology. New York, NY: Basic Books.

Lévi-Strauss, C. (1966). The Savage Mind. Chicago: University of Chicago Press. 
Mair, J., \& Marti, I. (2004). Social entrepreneurship: what are we talking about? A framework for future research. Working Paper 546, IESE Business School, University of Navarra.

Mair, J., \& Marti, I. (2006). Social entrepreneurship research: A source of explanation, prediction, and delight. Journal of World Business, 41(1), 36-44.

Mair, J., Battilana, J., \& Cardenas, J. (2012). Organizing for society: A typology of social entrepreneuring models. Journal of Business Ethics, 111(3), 353-373.

Martin, J. (1990). Deconstructing organizational taboos: The suppression of gender conflict in organizations. Organization Science, 1(4), 339-359.

Moorman, C., \& Miner, A. S. (1998). Organizational improvisation and organizational memory. Academy of Management Review, 23(4), 698723.

Morel, B., \& Ramanujam, R. (1999). Through the looking glass of complexity: The dynamics of organizations as adaptive and evolving systems. Organization Science, 10(3), 278-293.

Papzan, A., Afsharzade, N., \& Moradi, K. (2013). Entrepreneurial intention determinants: An empirical model and a case of Iranian students in Malaysia. Journal of Entrepreneurship, Management \& Innovation, 9(3), 43-55.

Pellegrini, M.M., Ciappei, C., Zollo, L., \& Boccardi, A. (2016). Finding the extraordinary and creating the unexpected: Perspicacity and genius combined in an entrepreneurial decision-making paradigm. Journal of Management Development, 35(6), 789-801.

Pellegrini, M.M., Rialti, R., Ciappei, C., \& Zollo, L. (forthcoming). Turnaround management and systemic approach: A historical review of the Florentine management school contribution. International Journal of Critical Accounting. Accepted for publication.

Peredo, A.M., \& McLean, M. (2006). Social entrepreneurship: A critical review of the concept. Journal of World Business, 41(1), 56-65.

Perrini, F., Vurro, C., \& Costanzo, L.A. (2010). A process-based view of social entrepreneurship: From opportunity identification to scaling-up social change in the case of San Patrignano. Entrepreneurship and Regional Development, 22(6), 515-534.

Pettigrew, A. (1990). Longitudinal field research on change: Theory and practice. Organization Science, 1(3), 267-92.

Rialti, R., Pellegrini, M.M., Caputo, A., \& Dabic, M. (2017). Entrepreneurial education and internationalization of firms in transition economies: A conceptual framework from the case of Croatia. World Review of Entrepreneurship, Management and Sustainable Development, 13(2-3), 290-313.

Sarasvathy, S.D. (2001). Causation and effectuation: Towards a theoretical shift from economic inevitability to entrepreneurial contingency. Academy of Management Review, 26(2), 243-288. 
Sarasvathy, S.D. (2008). Effectuation: Elements of Entrepreneurial Expertise. New Horizons in Entrepreneurship Research. Cheltenham, UK: Edward Elgar.

Shane, S., \& Venkataraman, S. (2000). The promise of entrepreneurship as a field of research. Academy of Management Review, 25(1), 217-226.

Stacey, R.D. (1995). The science of complexity: An alternative perspective for strategic change processes. Strategic Management Journal, 16(6), 477-495.

Starnawska, M. (2015). Social entrepreneurship and its hybridity determining resource challenges and chances. Studia Oeconomica Posnaniensia, 4(5), 38-53.

Stevenson, H.H., \& Jarillo, J.C. (1990). A paradigm of entrepreneurship: Entrepreneurial management. Strategic Management Journal, 11(5), 17-27.

Steyaert, C., \& Katz, J. (2004). Reclaiming the space of entrepreneurship in society: Geographical, discursive and social dimensions. Entrepreneurship and Regional Development, 16(3), 179-196.

Tan, W.L., Williams, J., \& Tan, T.M. (2005). Defining the 'social' in 'social entrepreneurship': Altruism and entrepreneurship. International Entrepreneurship and Management Journal, 1(3), 353-365.

Tapsell, P., \& Woods, C. (2010). Social entrepreneurship and innovation: Selforganization in an indigenous context. Entrepreneurship and Regional Development, 22(6), 535-556.

Van de Ven, A.H., \& Huber, G.P. (1990). Longitudinal field research methods for studying processes of organizational change. Organization Science, 1(3), 213-219.

Wengraf, T. (2001). Qualitative Research Interviewing: Biographic Narrative and Semi-Structured Methods. Thousand Oaks, CA: Sage Publications Inc.

Yin, R. (2013). Case Study Research: Design and Methods. Thousand Oaks, CA: Sage Publications Inc.

Zahra, S.A., Gedajlovic, E., Neubaum, D.O., \& Shulman, J.M. (2009). A typology of social entrepreneurs: Motives, search processes and ethical challenges. Journal of Business Venturing, 24(5), 519-532.

Zollo, L., Marzi, G., Boccardi, A., \& Surchi, M. (2015). How to match technological and social innovation: Insights from the biomedical $3 \mathrm{~d}$ printing industry. International Journal of Transitions and Innovation Systems, 4(1/2), 80-95.

Zollo, L., Faldetta, G., Pellegrini, M.M., \& Ciappei, C. (2016a, January). Volunteers' behavioral intention in non-profit organizations strategy: A structural equation model. In Academy of Management Proceedings (Vol. 1, p. 12995).

Zollo, L., Rialti, R., Ciappei, C., \& Pellegrini, M.M. (2016b). Factors stimulating social innovation in entrepreneurship: An empirical evidence of interorganizational alliances in Italy. International Journal of Business and Management, 11(5), 12-19. 
Zollo, L., Pellegrini, M., \& Ciappei, C. (2016c). What sparks ethical decision making? The interplay between moral intuition and moral reasoning: lessons from the scholastic doctrine. Journal of Business Ethics, 145(4), 681-700.

Zollo, L., Laudano, M.C., Ciappei, C., \& Zampi, V. (2017a). Factors affecting universities' ability to foster students' entrepreneurial behaviour: An empirical investigation. Journal of Management Development, 36(2), 268-285.

Zollo, L., Pellegrini, M.M., Faldetta, G., \& Rialti, R. (2017b). The sustainable path of social enterprises toward hybridity: Insights from a multiple case study of Italian NPOs. Proceedings of 17th European Academy of Management - ISSN 2466-7498.

Zollo, L., Rialti, R., Ciappei, C., \& Boccardi, A. (2017c). Reframing social entrepreneurship to address unexpected emergent social needs: An entrepreneurial bricolage perspective. Proceedings of 17th European Academy of Management - ISSN 2466-7498.

Zollo, L., Faldetta, G., Pellegrini, M., \& Ciappei, C. (forthcoming). Reciprocity and gift-giving logic in NPOs. Journal of Managerial Psychology. Accepted for publication.

\begin{abstract}
Abstrakt
Przedsiębiorczość społeczna jest jednq z najczęściej poruszanych kwestii w najnowszej literaturze zarzq̨dzania. Szczególnym zainteresowaniem badaczy stały się kwestie zwiqzane z aspektem socjologicznym i antropologicznym przedsiębiorczości społecznej. Prezentowany tekst koncentruje się na pojęciu „brikolażu” Claude Lévi-Strauss's i na sposobie w jaki może to myślenie wpływać na zaspokajenie potrzeb społecznych. Opierajqc się na postmodernistycznej perspektywie filozoficznej, nazwanq przez Jacques'a Derrida „dekonstrukcjq”, Autorzy próbujq przeanalizować zjawisko brikolażu w kontekście przedsiębiorczości społecznej. Na podstawie wyników pochodzących z pogłębionych podłużnych studiów przypadków, Autorzy zaproponowali swojq koncepcję teoretycznq możliwych, przedsiębiorczych rozwiq̨zań w odpowiedzi na potrzeby społeczne, poszukujqc roli brikolażu, która w konsekwencji została zinterpretowana jako odpowiednia szansa na zaspokojenie konkretnych potrzeb społecznych, które powinniśmy definiować, w znaczeniu takim, jakim się pojawiaja.
\end{abstract}

Słowa kluczowe: przedsiębiorczość społeczna, brikolaż, organizacje non-profit, dekonstrukcjonizm, złożoność, zarzq̨dzanie sytuacyjne. 


\section{Biographical notes}

Lamberto Zollo is a Post-Doc Researcher in Management at the University of Florence. His research interests are in strategic management, business ethics and entrepreneurship. His research has been published in several international journals such as Journal of Business Ethics, Management Decision and Journal of Management Development.

Riccardo Rialti is a Ph.D. Student in Management and Business Administration at the University of Florence. His research interests are in Management Information Systems, Big Data, Strategic Marketing and Entrepreneurship. His research has been published in several international journals such as Management Decision and World Review of Entrepreneurship, Management and Sustainable Development.

Cristiano Ciappei is Full Professor of Management at the University of Florence. His research interests are in Strategic Management, Business Ethics and Entrepreneurship. His research has been published in several international journals such as Journal of Business Ethics, Management Decision and Journal of Management Development.

Andrea Boccardi is a Post-Doc Researcher at the University of Florence. His research interests are in Social Entrepreneurship, Business Ethics and NonProfit Organizations. His research has been published in several international journals such Journal of Management Development. 
